\title{
To Other and Vilify: Manufacturing Migration as Crime
}

\author{
Gabriella Sanchez ${ }^{1}$
}

Published online: 17 April 2021

(C) The Author(s), under exclusive licence to Springer Nature B.V. 2021

This special issue of the European Journal on Criminal Policy and Research brings together empirical analyses into the criminalisation of practices related to migration and its implications on human rights. Drawing from the experiences of male and female migrants, civil society, ordinary citizens, brokers and smuggling facilitators and their encounters with law enforcement, this collection reduces this gap and raises questions concerning the way criminal law and policy around the world shapes migrant people's access to justice.

Over the last decade, there has been a proliferation of literature problematising the ways in which migration law and criminal law have increasingly come together. Authors have specifically examined how legislation, policy and decision-making concerning migration enforcement and border controls have progressively designated as criminal those lacking access to legal, safe and orderly migration, and their efforts to reach destinations elsewhere, build their lives, and thrive.

This body of work has been pivotal at highlighting the dynamics of migration and the increasing patterns of criminalisation migrants face (Bhatia et al., 2020). In many instances, it has also been an important tool when advocating for the rights and protection of people on the migration pathway and their entanglements with the law by showing how they often face additional burdens that shape the ways in which they are subjected to "processes of differentiation and exclusion" (Bosworth, 2019: 81).

However, this literature has also had a tendency to emphasise specific notions or perceptions about migration. It has often left aside a central social process at its core: the construction of race and citizenship, a troubling disconnect when considering that those who become the target of enforcement and control are quite often racialised men and women of colour. Workplace raids, midnight searches, city ordinances and changes in social services legislation are only some of the acts that are consistently used against specific, racialised groups to perpetuate their oppression and subordination (Gross-Wyrtzen \& Gazzotti, 2020; Sanchez \& Romero, 2010; Tyszler, 2020).

Tendencies in migration research do not end there: some migrant trajectories or destinations are discussed more frequently than others, often reinforcing their construction in mainstream discourse as problematic (e.g., the transits of migrants are depicted as uni-directional, seeking solely to reach destinations in the global north or posing security threats to its stability) (van Houtum \& Bueno Lacy, 2020). Literature has also

Gabriella Sanchez

gasa@diis.dk

1 Migration and Global Order Unit, Danish Institute for International Studies, Copenhagen, Denmark 
reproduced euro or US-centric perspectives often relying on depictions of criminal activity, which despite their attempts at being critical reinscribe racialised fears of the migrant other (Fiddian-Qasmiyeh, 2020; Rzepnikowska, 2019). Specific enforcement dynamics become examined to the point that they become paradigmatic, pushing aside and in some instances even making altogether invisible practices in other countries or corridors - the hyper-emphasis on Libya's migrant detention dynamics over those in other countries across North Africa (Al-Arabi, 2018; Sanchez et al., forthcoming), for example, come to mind. Of concern is also the privileging of criminal justice perspectives at articulating or explaining specific migratory practices (Baird \& van Liempt, 2016). This has, for example, systematically depicted smuggling as a form of transnational organised crime, despite the evidence that shows how the EU has increasingly manufactured local economic systems of mobility and trade as smuggling as part of efforts to control irregular migration into Europe (Brachet, 2018).

This special issue brings together contributions that explore some of these under-examined spaces and dynamics. The authors detail the interactions between migrant smuggling facilitators and migrants travelling clandestinely into the EU to reach the UK and examine the allegations transforming search and rescue operations and other activities by civil society from humanitarian acts into crimes. Contributions also examine how the depiction of irregular migration and its facilitation as external to the EU and as a third-country concern have allowed us collectively to turn a blind eye to the criminalisation that migrants also face as they travel irregularly across Europe. Examples from Myanmar, Peru and the USA also show how alleged efforts to protect migrants from exploitation often turn into yet another obstacle they must overcome in order to achieve mobility but also to preserve their dignity.

Paolo Campana and Loraine Gelsthorpe, drawing from interviews carried out in the UK and Greece with migrants about their interactions with migrant smugglers, examine the risk management strategies developed by both sets of actors in what constitutes a vastly asymmetrical and illegal market characterised by the scarcity of trust. Furthermore, while smugglers are often showcased in the literature as almost inherently violent, sexual predators with almost preternatural greed, this article problematises that one-sided view by documenting how they often find themselves cheated of fees, reported to police or even victimised.

Two articles examine the criminalisation of civil society in Europe, and their gradual labelling as migrant smugglers, and/or as "pull-factors" leading to increases in the number of irregular arrivals to Europe. First, Jennifer Allsop, Lina Vosyliute and Stephanie Smialowski trace how civil society organisations and individual volunteers, once considered benevolent humanitarians, suddenly saw their work re-labelled as conducive of irregular migration. Acts that would have otherwise been considered as humanitarian became gradually construed as criminal acts that had to be monitored, deterred and punished.

Secondly, Eugenio Cusumano and Matteo Villa turn to Italy to examine how non-governmental organisations (NGOs), having once played a crucial role in Search and Rescue (SAR) operations off the Libyan coast, (it is estimated they assisted almost 120,000 migrants in the 2014-2019 timeframe) suddenly found themselves as the main actors of legal claims alleging their collusion with smugglers operating out of Libya. While repeteadly found to be unsubstantiated, Cusumano and Villa argue that the claims shifted European decision-makers and public opinion against NGO SAR operations, and caused sea rescue NGOs to face policy restrictions, judicial criminalisation and broader social delegitimisation. 
Roxane de Massol de Rebetz focuses on the challenges of making clear-cut distinctions between migrant smuggling and human trafficking. To do so, she turns the table on the EU's ways of talking and engaging with both crimes within Schengen. While traditionally the EU has constructed the narrative of smuggling and irregular migration as occurring outside the EU's borders, the article argues the vulnerabilities migrants in transit face within the Schengen area do not fit the legal categories defined by human trafficking or migrant smuggling. Her work interrogates the taken-for-granted narratives of smuggling and trafficking that facilitate the criminalisation of those who continue to pursue journeys having reached Europe.

Also turning the look inward, Rebecca Galemba takes us to the streets of Denver, in the USA, to take a close look at the experiences of day labourers. These are men, primarily of Central American and Mexican origin, who informally sell their services as repairmen, gathering at corners or parking lots of large home improvement stores across the city. Racism and discrimination often result in them being harassed by ordinary people and law enforcement, the latter being often reluctant to protect labourers when employers refuse to compensate them for work already performed. The work of local activists has been effective at documenting abuses and holding employers accountable in court. Furthermore, these efforts have showcased how practices like wage theft and labour-based traffickingoften present in the low-wage work experiences of male and female migrants of colour in the USA - are neither properly recognised nor addressed by the court system nor labour law.

Feline Freire and Leda Perez's contribution also takes a look at how the presence of migrant workers in the public space can be construed from benevolent to criminal and even violent. Through interviews and focus groups with Venezuelan migrants in Peru, Freire and Perez identify how migrants experience discrimination by a society which despite having initially welcomed them, soon realised their common precarity put them at odds with one another. The article shows how Peruvians developed ways to other and vilify the new comers through their construction as violent, predatory and deviant.

Closing the special issue, Priya Deshingkar examines the implications of the decision by the government of Myanmar to ban women's migration to Singapore between 2014 and April 2019. The measure, part of a larger, global wave of reforms aimed to allegedly counter exploitation and eliminate the risk of the so-called modern-day slavery, put instead migrant women at risk. The ban did not stop the migration of women. Troublingly, it led to the emergence of an underground market, where the costs related to the facilitation of irregular migration and placement increased; women received inadequate predeparture training; their work conditions, without the support from Myanmar's government, were no longer monitored, many enduring abuse at the hands of their employers. While the ban was eventually lifted, the mechanisms that had allowed women to travel legally were permanently damaged, despite Myanmar's government's rush to respond to the alleged threat of human trafficking following international pressure.

\section{References}

Al-Arabi, A. (2018). Local specificities of migration in Libya: challenges and solutions. Policy Brief, Middle East Directions 2018/4. European University Institute. Retrieved from: https://cadmus.eui.eu/handle/1814/52585. 
Baird, T., \& van Liempt, I. (2016). Scrutinising the double disadvantage: Knowledge production in the messy field of migrant smuggling. Journal of Ethnic and Migration Studies, 42(3), 400-417.

Bhatia, M., Lousley, G., \& Turnbull, S. (2020). Introduction to the special issue: migration, vulnerability and violence. International Journal for Crime, Justice and Social Democracy, 9(3), 1-4.

Bosworth, M. (2019). Immigration detention, punishment and the transformation of justice. Social \& Legal Studies, 28(1), 81-99.

Brachet, J. (2018). Manufacturing smugglers: From irregular to clandestine mobility in the Sahara. The Annals of the American Academy of Political and Social Science, 676(1), 16-35.

Fiddian-Qasmiyeh, E. (2020). Introduction: Recentering the South in Studies of Migration. Migration and Society, 3(1), 1-18.

Gross-Wyrtzen, L., \& Gazzotti, L. (2020). Telling histories of the present: Postcolonial perspectives on Morocco's 'radically new' migration policy. The Journal of North African Studies, 1-17.

Rzepnikowska, A. (2019). Racism and xenophobia experienced by Polish migrants in the UK before and after Brexit vote. Journal of Ethnic and Migration Studies, 45(1), 61-77.

Sanchez, G., Arrouche, K., Capasso, M. (forthcoming). Current trends and challenges in the facilitation of irregular migration in Tunisia, Algeria and Morocco. In Sanchez, G., ed. Beyond networks, militias and tribes: rethinking EU counter-smuggling policy and response. Policy Study. IEMed and Euromesco.

Sanchez, G., \& Romero, M. (2010). Critical race theory in the US sociology of immigration. Sociology Compass, 4(9), 779-788.

Tyszler, E. (2020). Humanitarianism and black female bodies: Violence and intimacy at the MoroccanSpanish border. The Journal of North African Studies, 1-19.

van Houtum, H., \& Bueno Lacy, R. (2020). The migration map trap. On the invasion arrows in the cartography of migration. Mobilities, 15(2), 196-219.

Publisher's Note Springer Nature remains neutral with regard to jurisdictional claims in published maps and institutional affiliations. 